\title{
Reproductive cycle of Arvicola sapidus (Rodentia, Arvicolidae) from southern Navarre, Spain
}

\author{
Juan M. GARDE and M. Carmen ESCALA
}

Garde J. M. and Escala M. C. 1996. Reproductive cycle of Arvicola sapidus (Rodentia, Arvicolidae) from southern Navarre, Spain. Acta Theriologica 41: 353-365.

Development of sexual maturity and reproductive activity in Arvicola sapidus Miller, 1908, was studied. The sample analyzed consisted of 374 specimens (208 males and 166 females), captured in various localities in southern Navarre (Spain). Maturity and sexual activity of the males were evaluated both from the cytological analysis of testicular and epididymal tissues and by the testicular and vesicular size. Maturity and sexual activity of the females were determined as a function of the vulva condition, size and vascularization of the uterus, presence of embryos and placental scars, histological analysis of the ovary and development of the mammary glands. The results show that sexual maturity development is related to age, season and size of both the individual and its reproductive organs. In the studied population there are males with spermatozoa present throughout the entire year. However, the size of testes and seminal vesicles of the adult males varied yearly, reaching lowest values at the end of autumn and winter. The mean number of embryos per litter is $3.7 \pm 1.4(n=51$, range: $1-7$ ), being closely related to the mother's weight. Intrauterine mortality affects at leats $5.1 \%$ of the embryos and $17.6 \%$ of the litters, while $53.7 \%$ of the females show placental scars. Females show high sexual activity between March and October (46.1-90.0\% are pregnant or nursing) and are less active in the remaining months. In southern Navarre, $A$. sapidus breeds throughout the year with two well differentiated periods, one of high reproductive intensity (March-October, with maximum between April and June), and another of lesser intensity (November-February).

Department of Zoology and Ecology, Faculty of Sciences, University of Navarra, 31080 Pamplona, Spain

Key words: Arvicola sapidus, reproduction, Spain

\section{Introduction}

The water vole Arvicola sapidus Miller, 1908 lives closely tied to the presence of water: rivers, streams, ravines, ponds, etc. Its area of distribution covers the Iberian Peninsula and the south, centre and north-west of France (Cabrera 1914, Reichstein 1982).

Information on the reproductive biology of this species is very scarce. The most detailed works referring to this subject were conducted by Delost (1968) in a study on a population near the Tarn river (France) and by Ventura and Gosálbez (1987) and Ventura (1988) at the Ebro Delta (Spain). Other works (see Gosálbez 1982, Zabala 1983) gather information on the sexual state of specimens captured in isolation. 
The aim of this work is to analyze the characteristics of the reproductive biology and the reproductive cycle of $A$. sapidus in southern Navarre. The development of sexual maturity was studied, as well as its relation to various factors: age, morphological parametres, season and size of sexual organs. The male's sexual activity and various aspects of the female's pregnancy and nursing period are also analyzed, as well as the duration and intensity of the breeding season.

\section{Material and methods}

The sample analysed consists of 357 specimens of Arvicola sapidus (198 males and 159 females) captured in different localities in southern Navarre, between 1984 and 1986, plus 17 specimens (10 males and 7 females) obtained occasionally in 1983, 1988 and 1989. The diversification of the captures in time and space aimed at minimizing the impact of removal specimens on the low population density (Le Louarn and Saint-Girons 1977). This region, with an annual mean temperature of $13.5^{\circ} \mathrm{C}$ and approximately $450 \mathrm{~mm}$ annual rainfall, presents a climate of a semiarid and mesothermic type (Creus 1986) and falls within the Mediterranean biogeographic region (Báscones and Ursúa 1986). The area is traversed by various rivers and canals for irrigation and drainage, under the influence of which important hydrophilic communities develop, among which reeds and rushes stand out (Cl. Phragmitetea and Molinio-Arrhenateretea). The period of vegetative activity of these communities lasts from the end of March to the beginning of November.

The male's reproductive status was analysed by assessing the presence of spermatozoa in testicle and epididymis (see Gosálbez et al. 1979) as well as testicular size (TL - the testicle length and TW - weight of both testes) and vesicular weight (VW - weight of both seminal vesicles). In order to study the seasonal variation of testicle weight in adult mature males and remove the influence of the animal size (Garde and Escala 1993), the testicular index (Kenagy and Trombulak 1986) $(\mathrm{TI}=[(\mathrm{TW} \times 100) /$ body weight $])$ and the vesicular index $($ Garde 1992) $(\mathrm{VI}=[(\mathrm{VW} \times 100) /$ body weight $])$ have been estimated.

The female's reproductive maturity and activity were determined as a function of the state of the vulva (open or closed), size and vascularization of the uterus, presence and number of healthy embryos and those in resorption, and placental scars. The presence and number of placental scars are difficult to find in pregnant females, as the scars tend to vanish temporarily on the dilatated zones of the uterus, so that they have been disregarded to asses the number of gestations. In 20 females, the sexual status of which could not be determined macroscopically, follicular maturation was assessed histologically.

From the features shown, the following sexual categories were established (Ventura and Gosálbez, 1987, Garde 1992): (1) Immature - males without spermatozoa; females with a closed vulva, little developed and irrigated uterus, without embryos or placental scars. (2) Submature - males with few spermatozoa; females with moderately or completely open vulva, ovary with corpora lutea, little developed and irrigated uterus, without embryos or placental scars. (3) Mature - males with abundant spermatozoa; females with totally open vulva, very developed and irrigated uterus, with embryos and placental scars.

The duration and intensity of the breeding season were estimated from the female sexual activity (ratio of pregnant and nursing females with respect to mature ones). The male sexual activity was taken into account only secondarily (Pelikán 1972).

The following set of morphological and biometric features was analyzed: state of the moult and kinds of fur, body weight (BW), condylo-basal length (CBL), and eye lens weight (EW). According to these features the specimens were distributed in six classes $(0-\mathrm{V})$ of relative age (Garde et al. 1993): 


\begin{tabular}{llrrr}
\hline Class & \multicolumn{1}{c}{ Fur } & BW $(\mathrm{g})$ & CBL $(\mathrm{mm})$ & EW (mg) \\
\hline 0 & 1st fur & $33.0-78.9$ & $27.0-31.6$ & $5.3-9.2$ \\
I & 1st moult & $75.4-145.4$ & $31.1-36.7$ & $8.6-12.3$ \\
II & 2nd fur or beginning of 2nd moult & $125.3-176.1$ & $35.2-38.1$ & $11.0-18.6$ \\
III & end of 2nd fur & $147.8-225.5$ & $37.0-40.5$ & $14.6-22.0$ \\
IV & fur/moult of adult & $152.0-290.0$ & $38.3-41.7$ & $17.9-25.9$ \\
V & fur/moult of adult & $189.6-326.5$ & $39.3-44.0$ & $20.0-32.5$ \\
\hline
\end{tabular}

\section{Results}

\section{Males}

Attaining sexual maturity in Arvicola sapidus males is dependent upon the age, body size and time of birth of animals. The first mature males appear at age II and their proportion is progressively increasing until $100 \%$ at age V (Table 1).

Table 1. Males' distribution of Arvicola sapidus from southern Navarre as a function of relative age, month of capture and sexual state. $n$ - number of captured specimens (also in Tables 2-7).

\begin{tabular}{|c|c|c|c|c|c|c|c|c|c|c|c|c|c|}
\hline $\begin{array}{r}\text { Month } \\
n \\
\text { Age class }\end{array}$ & $\begin{array}{c}\text { Jan } \\
12\end{array}$ & $\begin{array}{c}\text { Feb } \\
15\end{array}$ & $\begin{array}{c}\text { Mar } \\
22\end{array}$ & $\begin{array}{c}\text { Apr } \\
23\end{array}$ & $\begin{array}{c}\text { May } \\
15\end{array}$ & $\begin{array}{c}\text { Jun } \\
17\end{array}$ & $\begin{array}{c}\text { Jul } \\
10\end{array}$ & $\begin{array}{c}\text { Aug } \\
16\end{array}$ & $\begin{array}{c}\text { Sep } \\
18\end{array}$ & $\begin{array}{c}\text { Oct } \\
19\end{array}$ & $\begin{array}{c}\text { Nov } \\
17\end{array}$ & $\begin{array}{c}\text { Dec } \\
24\end{array}$ & $\begin{array}{c}\text { Total } \\
208\end{array}$ \\
\hline 0 & - & - & - & - & - & - & - & - & - & - & 1 & 1 & 2 \\
\hline Immature & - & - & - & - & - & - & - & - & - & - & 1 & 1 & 2 \\
\hline I & - & - & - & - & 1 & 2 & 1 & - & 1 & 3 & 4 & 2 & 14 \\
\hline Immature & - & - & - & - & 1 & 2 & 1 & - & 1 & 2 & 3 & 2 & 12 \\
\hline Submature & - & - & - & - & - & - & - & - & - & 1 & 1 & - & 2 \\
\hline Mature & - & - & - & - & - & - & - & - & - & - & - & - & - \\
\hline II & 3 & - & - & - & 1 & 2 & 1 & 1 & 1 & 1 & 1 & 1 & 12 \\
\hline Immature & 2 & - & - & - & - & - & - & - & - & 1 & - & 1 & 4 \\
\hline Submature & 1 & - & - & - & - & - & - & - & - & - & 1 & - & 2 \\
\hline Mature & - & - & - & - & 1 & 2 & 1 & 1 & 1 & - & - & - & 6 \\
\hline III & 3 & 4 & 3 & 1 & 1 & - & 1 & 2 & 9 & 6 & 3 & 3 & 36 \\
\hline Immature & 2 & - & - & - & - & - & - & - & 1 & 1 & - & 1 & 5 \\
\hline Submature & 1 & 2 & - & - & - & - & - & - & - & - & 2 & - & 5 \\
\hline Mature & - & 2 & 3 & 1 & 1 & - & 1 & 2 & 8 & 5 & 1 & 2 & 26 \\
\hline IV & 4 & 5 & 10 & 11 & 5 & 3 & 2 & 4 & 1 & 5 & 4 & 13 & 67 \\
\hline Immature & - & - & - & - & - & - & - & - & - & - & 1 & 5 & 6 \\
\hline Submature & 1 & 1 & - & - & - & - & - & - & - & - & - & 1 & 3 \\
\hline Mature & 3 & 4 & 10 & 11 & 5 & 3 & 2 & 4 & 1 & 5 & 3 & 7 & 58 \\
\hline V & 2 & 6 & 9 & 11 & 7 & 10 & 5 & 9 & 6 & 4 & 4 & 4 & 77 \\
\hline Mature & 2 & 6 & 9 & 11 & 7 & 10 & 5 & 9 & 6 & 4 & 4 & 4 & 77 \\
\hline
\end{tabular}


Table 2. Proportion of sexually mature specimens of Arvicola sapidus from southern Navarre as a function of the body weight intervals considered.

\begin{tabular}{lrcccc}
\hline & Weight $(\mathrm{g}):<140$ & $140-180$ & $180-220$ & $>220$ & Total \\
\hline $\begin{array}{l}\text { Males }(n) \\
\% \text { of mature }\end{array}$ & 17 & 27 & 54 & 106 & 204 \\
& 0 & 59 & 83 & 100 & \\
Females $(n)$ & 18 & 34 & 43 & 59 & 154 \\
$\%$ of mature & 0 & 50 & 86 & 100 & \\
\hline
\end{tabular}

It must be noticed that those non-mature individuals which have appeared from age II were captured during the autumn and winter months.

The point of sexual maturity acquisition is associated with body weight (Table 2). Submature males are found from a $114 \mathrm{~g}$ weight and mature ones weigh more than $145 \mathrm{~g}$. Nevertheless in autumn and winter immature individuals of $211 \mathrm{~g}$ are found as well as submature ones of $208 \mathrm{~g}$. All the specimens may be considered mature above approximately $211 \mathrm{~g}$.

Relationship between testis and seminal vesicle size and sexual development is observed. Testis length (TL) oscillates between $4.0-19.4 \mathrm{~mm}$ and vesicle weight (VW) between 0.01-7.57 g. First spermatozoa appear at TL $=5.3 \mathrm{~mm}$ and VW $=$ $0.01 \mathrm{~g}$. Mature individuals appear from $\mathrm{TL}=11.3 \mathrm{~mm}$ and $\mathrm{VW}=0.11 \mathrm{~g}$. All males are mature from $\mathrm{TL}=12.3 \mathrm{~mm}$ and $\mathrm{VW}=1.10 \mathrm{~g}$. The correlation between testis and vesicle size is very high $\left(r_{\mathrm{P}}=0.792, n=167, p<0.001\right)$.

The reproductive organ size increases with the animal relative age (Table 3 ). The most important growth is observed between age classes I-II and II-III, in association with the acquisition of sexual maturity at these ages (Table 1). The regression equation between both organs $(\log \mathrm{VW}=-0.0695+1.8287 \times \log \mathrm{TW}$,

Table 3. Values of testicle length (TL in $\mathrm{mm}$ ) and seminal vesicle weight (VW in $\mathrm{g}$ ) of Arvicola sapidus from southern Navarre, as a function of relative age.

\begin{tabular}{rrrrrr}
\hline & Age class & $n$ & Avg & SD & \multicolumn{1}{l}{ Range } \\
\hline TL & 0 & 2 & 4.50 & 0.71 & $4.0-5.0$ \\
& I & 14 & 5.21 & 0.89 & $4.0-7.4$ \\
& II & 12 & 10.18 & 3.20 & $5.0-14.0$ \\
& III & 34 & 13.00 & 2.56 & $7.0-16.4$ \\
& IV & 58 & 14.39 & 2.86 & $6.0-19.0$ \\
& V & 66 & 16.67 & 1.38 & $13.4-19.4$ \\
& & 2 & 0.02 & 0.01 & $0.02-0.03$ \\
VW & I & 13 & 0.01 & 0.00 & $0.01-0.02$ \\
& I & 9 & 0.34 & 0.46 & $0.01-1.31$ \\
& II & 29 & 0.93 & 0.94 & $0.01-2.55$ \\
& III & 55 & 1.81 & 1.31 & $0.01-5.08$ \\
IV & 62 & 2.82 & 1.59 & $0.34-7.57$ \\
\hline
\end{tabular}


Table 4. Values of testes length (TL) and seminal weight (VW) of Arvicola sapidus from southern Navarre, as a function of relative age and period of capture. SS - spring-summer, AW - autumn-winter, $t$ - value of Student's test corresponding to the comparisons between the aforesaid seasonal period, $p$ - significance level of the test, ${ }^{*}-p<0.05,{ }^{* *}-p<0.01,^{* * *}-p<0.001$.

\begin{tabular}{|c|c|c|c|c|c|c|c|c|}
\hline & Age class & Period & $n$ & Avg & $\mathrm{SD}$ & Range & $t$ & $p$ \\
\hline \multirow[t]{4}{*}{ TL } & II & $\begin{array}{l}\text { SS } \\
\text { AW }\end{array}$ & $\begin{array}{l}5 \\
7\end{array}$ & $\begin{array}{r}12.88 \\
8.24\end{array}$ & $\begin{array}{l}0.98 \\
2.77\end{array}$ & $\begin{array}{r}11.3-14.0 \\
5.0-13.7\end{array}$ & & \\
\hline & III & $\begin{array}{l}\mathrm{SS} \\
\mathrm{AW}\end{array}$ & $\begin{array}{l}10 \\
24\end{array}$ & $\begin{array}{l}14.66 \\
12.31\end{array}$ & $\begin{array}{l}1.10 \\
2.69\end{array}$ & $\begin{array}{r}12.0-15.9 \\
7.0-16.4\end{array}$ & 2.6523 & * \\
\hline & IV & $\begin{array}{l}\text { SS } \\
\text { AW }\end{array}$ & $\begin{array}{l}21 \\
37\end{array}$ & $\begin{array}{l}15.73 \\
13.63\end{array}$ & $\begin{array}{l}1.32 \\
3.21\end{array}$ & $\begin{array}{r}13.8-18.5 \\
6.0-19.0\end{array}$ & 2.8553 & * \\
\hline & V & $\begin{array}{l}\mathrm{SS} \\
\mathrm{AW}\end{array}$ & $\begin{array}{l}45 \\
21\end{array}$ & $\begin{array}{l}16.98 \\
15.99\end{array}$ & $\begin{array}{l}1.15 \\
1.60\end{array}$ & $\begin{array}{l}14.6-19.4 \\
13.4-19.2\end{array}$ & 28654 & $*$ \\
\hline \multirow[t]{4}{*}{ VW } & II & $\begin{array}{l}\text { SS } \\
\mathrm{AW}\end{array}$ & $\begin{array}{l}4 \\
5\end{array}$ & $\begin{array}{l}0.54 \\
0.18\end{array}$ & $\begin{array}{l}0.54 \\
0.36\end{array}$ & $\begin{array}{l}0.11-1.31 \\
0.01-0.83\end{array}$ & & \\
\hline & III & $\begin{array}{l}\text { SS } \\
\mathrm{AW}\end{array}$ & $\begin{array}{r}8 \\
21\end{array}$ & $\begin{array}{l}1.57 \\
0.68\end{array}$ & $\begin{array}{l}0.75 \\
0.91\end{array}$ & $\begin{array}{l}0.43-2.46 \\
0.01-2.55\end{array}$ & 2.4584 & * \\
\hline & IV & $\begin{array}{l}\text { SS } \\
\text { AW }\end{array}$ & $\begin{array}{l}18 \\
37\end{array}$ & $\begin{array}{l}2.72 \\
1.37\end{array}$ & $\begin{array}{l}1.26 \\
1.11\end{array}$ & $\begin{array}{l}1.00-5.08 \\
0.01-3.62\end{array}$ & 4.0490 & $* * *$ \\
\hline & V & $\begin{array}{l}\text { SS } \\
\text { AW }\end{array}$ & $\begin{array}{l}42 \\
20\end{array}$ & $\begin{array}{l}3.20 \\
2.04\end{array}$ & $\begin{array}{l}1.60 \\
1.27\end{array}$ & $\begin{array}{l}0.88-7.57 \\
0.34-4.04\end{array}$ & 2.8939 & $* *$ \\
\hline
\end{tabular}

Table 5. Monthly and seasonal values of testicular (TI) and vesicular (VI) indexes of the mature and adult males (age classes IV and V) of Arvicola sapidus from southern Navarre.

\begin{tabular}{|c|c|c|c|c|c|c|}
\hline \multirow{2}{*}{ Month } & \multicolumn{3}{|c|}{$\mathrm{TI}$} & \multicolumn{3}{|c|}{ VI } \\
\hline & $n$ & Avg & SD & $n$ & Avg & $\mathrm{SD}$ \\
\hline January & 5 & 0.526 & 0.138 & 5 & 0.556 & 0.317 \\
\hline February & 3 & 0.552 & 0.159 & 3 & 0.540 & 0.297 \\
\hline March & 12 & 0.599 & 0.124 & 12 & 1.005 & 0.337 \\
\hline April & 14 & 0.700 & 0.105 & 14 & 1.111 & 0.534 \\
\hline May & 8 & 0.809 & 0.178 & 8 & 1.209 & 0.388 \\
\hline June & 13 & 0.706 & 0.150 & 13 & 1.130 & 0.732 \\
\hline July & 7 & 0.679 & 0.142 & 7 & 1.159 & 0.381 \\
\hline August & 11 & 0.798 & 0.257 & 11 & 1.750 & 0.446 \\
\hline September & 7 & 0.703 & 0.126 & 7 & 1.185 & 0.209 \\
\hline October & 8 & 0.685 & 0.118 & 7 & 1.173 & 0.281 \\
\hline November & 6 & 0.472 & 0.205 & 6 & 0.453 & 0.367 \\
\hline December & 11 & 0.509 & 0.160 & 11 & 0.584 & 0.435 \\
\hline Spring & 33 & 0.721 & 0.148 & 33 & 1.055 & 0.500 \\
\hline Summer & 27 & 0.740 & 0.194 & 27 & 1.479 & 0.525 \\
\hline Autumn & 21 & 0.627 & 0.175 & 20 & 0.900 & 0.456 \\
\hline Winter & 24 & 0.515 & 0.122 & 24 & 0.694 & 0.427 \\
\hline
\end{tabular}


Table 6. Females' distribution of Arvicola sapidus from southern Navarre as a function of relative age, month of capture and sexual state.

\begin{tabular}{|c|c|c|c|c|c|c|c|c|c|c|c|c|c|}
\hline $\begin{array}{l}\text { Month: } \\
n: \\
\text { Age class }\end{array}$ & $\begin{array}{c}\text { Jan } \\
10\end{array}$ & $\begin{array}{c}\text { Feb } \\
13\end{array}$ & $\begin{array}{c}\text { Mar } \\
18\end{array}$ & $\begin{array}{c}\text { Apr } \\
11\end{array}$ & $\begin{array}{c}\text { May } \\
12\end{array}$ & $\begin{array}{c}\text { Jun } \\
11\end{array}$ & $\begin{array}{c}\text { Jul } \\
11\end{array}$ & $\begin{array}{c}\text { Aug } \\
20\end{array}$ & $\begin{array}{c}\text { Sep } \\
11\end{array}$ & $\begin{array}{c}\text { Oct } \\
13\end{array}$ & $\begin{array}{c}\text { Nov } \\
10\end{array}$ & $\begin{array}{c}\text { Dec } \\
26\end{array}$ & $\begin{array}{c}\text { Total } \\
166\end{array}$ \\
\hline 0 & - & - & - & - & 3 & - & - & - & 1 & - & 2 & - & 6 \\
\hline Immature & - & - & - & - & 3 & - & - & - & 1 & - & 2 & - & 6 \\
\hline I & - & - & - & 1 & - & 1 & - & 4 & 1 & 2 & 1 & 2 & 12 \\
\hline Immature & - & - & - & 1 & - & 1 & - & 4 & 1 & 2 & 1 & 2 & 12 \\
\hline Submature & - & - & - & - & - & - & - & - & - & - & - & - & - \\
\hline Mature & - & - & - & - & - & - & - & - & - & - & - & - & - \\
\hline II & 1 & - & - & - & - & 1 & 2 & 4 & 1 & 3 & 1 & 2 & 15 \\
\hline Immature & 1 & - & - & - & - & - & 1 & - & - & 2 & 1 & 2 & 7 \\
\hline Submature & - & - & - & - & - & - & - & 2 & - & - & - & - & 2 \\
\hline Mature & - & - & - & - & - & 1 & 1 & 2 & 1 & 1 & - & - & 6 \\
\hline III & 2 & 5 & 2 & 1 & 1 & - & 2 & 4 & - & 2 & - & 7 & 26 \\
\hline Immature & 1 & 4 & - & 1 & - & - & - & - & - & - & - & 3 & 9 \\
\hline Submature & 1 & 1 & 1 & - & - & - & - & 1 & - & - & - & 3 & 7 \\
\hline Mature & - & - & 1 & - & 1 & - & 2 & 3 & - & 2 & - & 1 & 10 \\
\hline IV & 5 & 6 & 12 & 6 & 5 & 5 & 3 & 3 & 3 & 4 & 5 & 10 & 67 \\
\hline Immature & - & 1 & - & - & - & - & - & - & - & - & - & 1 & 2 \\
\hline Submature & - & 1 & - & - & - & - & - & - & - & - & - & - & 1 \\
\hline Mature & 5 & 4 & 12 & 6 & 5 & 5 & 3 & 3 & 3 & 4 & 5 & 9 & 64 \\
\hline V & 2 & 2 & 4 & 3 & 3 & 4 & 4 & 5 & 5 & 2 & 1 & 5 & 40 \\
\hline Mature & 2 & 2 & 4 & 3 & 3 & 4 & 4 & 5 & 5 & 2 & 1 & 5 & 40 \\
\hline
\end{tabular}

Table 7. Females' distribution of Arvicola sapidus from southern Navarre as a function of their sexual activity and month of capture. The percentage of pregnant refers to the number of mature specimens.

\begin{tabular}{|c|c|c|c|c|c|}
\hline \multirow{2}{*}{ Month } & \multirow{2}{*}{$\begin{array}{c}\text { Total } \\
n\end{array}$} & \multirow{2}{*}{$\begin{array}{c}\text { Mature } \\
n\end{array}$} & \multicolumn{2}{|c|}{ Pregnant } & \multirow{2}{*}{$\begin{array}{c}\text { Nursing } \\
n\end{array}$} \\
\hline & & & $n$ & $\%$ & \\
\hline January & 10 & 7 & 1 & 14 & 2 \\
\hline February & 13 & 6 & 1 & 17 & 0 \\
\hline March & 18 & 17 & 8 & 47 & 2 \\
\hline April & 11 & 9 & 6 & 67 & 4 \\
\hline May & 12 & 9 & 5 & 55 & 4 \\
\hline June & 11 & 10 & 3 & 30 & 7 \\
\hline July & 11 & 10 & 6 & 60 & 1 \\
\hline August & 20 & 13 & 6 & 46 & 4 \\
\hline September & 11 & 9 & 3 & 33 & 6 \\
\hline October & 13 & 9 & 5 & 55 & 3 \\
\hline November & 10 & 6 & 0 & 0 & 0 \\
\hline December & 26 & 15 & 7 & 47 & 3 \\
\hline Total & 166 & 120 & 51 & 42 & 36 \\
\hline
\end{tabular}


$R^{2}=0.8436, n=167$ ) brings out the positive allometric growth of vesicular weight above that of testicles.

To verify the possible differential growth of the sexual organs, as expressed by TL and VW, in relation to the male birth period, the specimens of the age classes II-V have been redistributed into two groups with respect to capture time: spring-summer (SS) and autumn-winter (AW). The results show that the reproductive organs of individuals of classes II and III, born during SS period, are larger, the differences being statistically significant and the animals reaching maturity earlier than the individuals of the AW period (Table 4).

In voles of relative age IV and V, the period of capture does not necessarily coincide with that of birth. Nevertheless, the significant differences of TL and VW between the two considered periods are mantained. These differences suggest the existence of some type of physiological process leading to size reduction in testes and vesicles during the AW period. The testicular (TI) and vesicular (VI) indexes for mature males of age classes IV and V (Table 5) undergo a remarkable yearly oscillation, which coincides with that shown by monthly mean temperature (TI: $r_{\mathrm{P}}=0.810, n=12, p<0.01$; VI: $r_{\mathrm{P}}=857, n=12, p<0.001$ ) and photoperiod (TI: $r_{\mathrm{P}}=0.850, n=12, p<0.001$; VI: $r_{\mathrm{P}}=774, n=12, p<0.01$ ), with which they are significantly correlated.

\section{Females}

A relationship exists between age and sexual maturity acquisition. Table 6 shows that all the females in age classes 0 and I are immature. From class II they start reaching puberty. Most individuals of classes II and III and all of class IV, which have not reached maturity, were captured in the autumn and winter months. All the females under $125 \mathrm{~g}$ of body weight are immature. The first mature females appear at $141 \mathrm{~g}$ and all those above $193 \mathrm{~g}$ are mature. Fifty $\%$ of the females are mature from the $140-180 \mathrm{~g}$ interval (Table 2), increasing the proportion in heavier intervals.

Out of 120 mature females analysed, 51 were pregnant. They were detected in all months, except November, but there were captures on 19th and 26th October, as well as on 2nd and 3rd December. The frequency of gestation, however, is not homogeneous during the entire year (Table 7). Although percentages undergo remarkable oscillations from one month to the next, the existence of two different periods can be observed: from March to October with high frequency of gestation (30-67\%), and from November to February with a lower one (0-47\%).

Out of the 51 analysed gestating females 187 embryos were counted, and those presenting macroscopic signs of reabsorption were discarded. The mean number of embryos per litter was $3.7 \pm 1.4$. The range of litter size varied from 1 to 7 embryos, 3 being the mode. The mean litter size over the year (Table 8) ranges from 2.8 to 4.7 embryos, when the seasonal statistical significance was not appreciated (Kruskal-Wallis test: $H=1.5671, \mathrm{~ns}$ ), and neither were periods of 
Table 8. Distribution of the number of embryos per litter of Arvicola sapidus from southern Navarre as a function of the different yearly periods considered. $\mathrm{N}$ - number of litters, $n$-number of embryos.

\begin{tabular}{|c|c|c|c|c|c|c|c|c|c|c|c|}
\hline \multirow{2}{*}{ Period } & \multirow{2}{*}{$\mathrm{N}$} & \multicolumn{7}{|c|}{ Embryos/litter } & \multirow{2}{*}{$n$} & \multirow{2}{*}{ Avg } & \multirow{2}{*}{$\mathrm{SL}$} \\
\hline & & 1 & 2 & 3 & 4 & 5 & 6 & 7 & & & \\
\hline January & 1 & - & - & - & 1 & - & - & - & 4 & 4.0 & - \\
\hline February & 1 & - & - & - & 1 & - & - & - & 4 & 4.0 & - \\
\hline March & 8 & - & 2 & 3 & 2 & - & - & 1 & 28 & 3.5 & 1.6 \\
\hline April & 6 & - & 1 & 2 & - & 1 & 1 & 1 & 26 & 4.3 & 2.0 \\
\hline May & 5 & - & 1 & 3 & - & 1 & - & - & 16 & 3.2 & 1.1 \\
\hline June & 3 & - & - & 1 & 1 & 1 & - & - & 12 & 4.0 & 1.0 \\
\hline July & 6 & - & 1 & 2 & 1 & 1 & 1 & - & 23 & 3.8 & 1.5 \\
\hline August & 6 & - & 2 & 3 & 1 & - & - & - & 17 & 2.8 & 0.7 \\
\hline September & 3 & - & - & 1 & - & 1 & 1 & - & 14 & 4.7 & 1.5 \\
\hline October & 5 & - & - & - & 3 & 1 & 1 & - & 23 & 4.6 & 0.9 \\
\hline November & - & - & - & - & - & - & - & - & - & - & - \\
\hline December & 7 & 2 & - & 3 & 1 & 1 & - & - & 20 & 2.9 & 1.5 \\
\hline Spring & 15 & - & 4 & 6 & 1 & 2 & 1 & 1 & 53 & 3.5 & 1.5 \\
\hline Summer & 13 & - & 3 & 5 & 2 & 2 & 1 & - & 45 & 3.5 & 1.3 \\
\hline Autumn & 13 & 1 & - & 4 & 4 & 2 & 2 & - & 51 & 3.9 & 1.4 \\
\hline Winter & 10 & 1 & - & 3 & 4 & 1 & - & 1 & 38 & 3.8 & 1.5 \\
\hline March-October & 42 & - & 7 & 15 & 8 & 6 & 4 & 2 & 159 & 3.8 & 1.4 \\
\hline November-February & 9 & 2 & - & 3 & 3 & 1 & - & - & 28 & 3.1 & 1.4 \\
\hline Total & 51 & 2 & 7 & 18 & 11 & 7 & 4 & 2 & 187 & 3.7 & 1.4 \\
\hline
\end{tabular}

greatest and lowest frequency of gestations (Mann-Whitney test, $n_{1}=9, n_{2}=42$, $p=0.1702$ ).

Gestating females were detected starting from age class III. A close relationship is apparent between the female weight and the number of embryos. A gradual constant increase in the mean litter size is observed, coinciding with the increase in the mother body weight, giving a significant correlation $\left(r_{\mathrm{P}}=0.573, n=51\right.$, $p<0.001$ ).

Ten embryos in resorption were observed (5.1\%), affecting 9 females (18\% of the gestating ones). Eight litters presented a single embryo in resorption and one presented two embryos, their maximal proportions being reached in May (12.5\% of embryos and $40 \%$ of gestating females) and in December (15.0\% and $43 \%$ respectively). As to the two periods of greatest and lowest gestational frequency, at least $14 \%$ of the females and $4.3 \%$ of the embryos undergo resorption in the March-October period, whereas resorption affects $33 \%$ of females and $9.7 \%$ of the embryos in the November-February period.

No relationship between female body weight and resorption of embryos was observed. However, there are associations between resorption and the mother age: 6 
belonged to class $\mathrm{V}$ ( $28 \%$ of the gestating ones of this class) and 3 to class IV $(11 \%)$.

Embryos in resorption were found in litters of different size (1-5 embryos), but those presenting unilateral implantation (33\% when they only entail $16 \%$ of the gestating ones), seem to be more affected. The mean size of the affected litter is 2.9 , lower than the mean of the population (3.7).

Placental scars were found in $65(54 \%)$ mature females of the analysed sample. There is a positive correlation between the proportion of females with maculae and relative age: $20 \%$ in class III, $56.2 \%$ in class IV and $65.8 \%$ in class V. In 17 instances scars were detected in uteri with embryos. And thus, $81.8 \%$ of the mature females presented maculae and/or foetuses.

The mean number of scars per uterus (ME) is $7.9 \pm 4.8$ ( $n=48$ uteri), which entails a little more than two gestations (2.2). The females belonging to class III, with a mean number of scars of $3.0 \pm 1.4(n=2)$, have experienced a single conception. Age IV, $\mathrm{ME}=6.4 \pm 2.9(n=30)$, have undergone a mean of almost two gestations (between $d$ and 4 ). Class $\mathrm{V}, \mathrm{ME}=11.4 \pm 6.0(n=16)$, have undergone a mean of three gestations (between 1 and 5.5). The detection of two uteri with 20 scars and two others with 19, one of these having three embryos as well, all belonging to class $\mathrm{V}$ females, suggests that some mothers could reach at least 6 gestations throughout their life.

Thirty six females, which included $29.7 \%$ of the mature ones were lactating (Table 7). This percentage varies according to season. It is high in spring (40.6\%), summer $(32.1 \%)$ and autumn $(37.0 \%)$ and very low in winter $(11.7 \%)$. Lactation and gestation were observed simultaneously in 17 females. This shows that, after a birth and during the lactating period, a sizable part of the female population can have an oestrus again with the consequent mating and new conception.

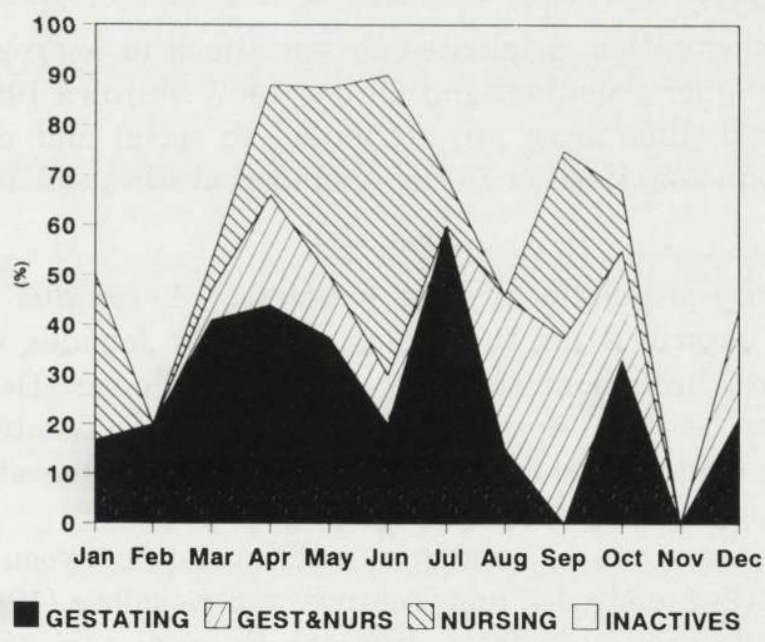

Fig. 1. Percentage of monthly distribution of mature females of Arvicola sapidus from southern Navarre, as a function of their different sexual activity states. 


\section{Reproductive cycle}

This study of the reproductive cycle was carried out on a sample of females captured uninterruptedly during the years 1984, 1985 and 1986. Nevertheless, to obtain representative monthly samples, specimens were grouped in a single yearly period (Fig. 1). These data on the females sexual activity, gestations and lactations, indicate that Arvicola sapidus in southern Navarre breeds almost throughout the year. The reproductive activity varies according to season: it is greatest in the March-October period (46.1-90.0\%), with a spring maximum between April and June (87.5-90.0\%), and lowest in the November-February period (0-50.0\%).

The sexual activity of the adult mature males, with testicular and vesicular indexes in Table 5, fluctuates in the same way as in the females. The oscillation of reproductive intensity is also similar to that undergone by the temperature and the photoperiod in this region, and similar, in the last instance, to the vegetation phenology cycle.

\section{Discussion}

Males

The reproduction model for the males of Arvicola sapidus described here, coincides basically with the one noted by Ventura and Gosálbez (1987). It confirms the close relationship between sexual maturity acquisition and age, body weight, testicle size and season, and it agrees with the observations carried out on other arvicolids (Newson 1963, Martinet and Spitz 1971, Rowlands and Weir 1984, Ventura 1988). The presence of males with spermatozoa during the entire year, coupled to the existence of a seasonal oscillation with winter depression in testicular and vesicular size, agrees with data from Delost (1968) and Ventura and Gosálbez (1987).

This type of fluctuation, originated by variations in androgen secretion, has been observed in other rodents (Saint-Girons 1967, Ventura 1988). The causes of these physiological differences are attributed to social and nutritional factors (Rissman and Johnston 1986) or to the photoperiod (Bronson 1988).

\section{Females}

Sexual maturity acquisition by the females of $A$. sapidus follows a pattern similar to that described for the males. Pregnant females were captured in southern Navarre throughout the year, except November. Delost (1968) found gestating females between April and September, while Ventura and Gosálbez (1987) mention a longer period (February-October) and suggest the possibility of winter reproduction.

The litter size was from 1-7 embryos, intermediate between the one observed by Delost (1968) (2-8 embryos) and Ventura and Gosálbez (1987) (2-5). Results from small samples collected from different Spanish regions (Gosálbez 1982, Zabala 1983, Garde 1992) suggest an amplitude of 1-8 embryos. 
The mean embryos per litter (3.7) is somewhat greater than the one noted by Ventura and Gosálbez (1987) (3.3), who suggest a relationship between litter size and the mother body weight. This fact is fully confirmed in this work and coincides with the observations carried out in other arvicolids (Pelikán 1972, Ventura 1988). The intrauterine mortality observed in A. sapidus, already pointed out by Ventura (1988) in one female, is a common fact in other rodents (Pelikán 1972, Durán et al. 1987).

Ventura (1988) found a low proportion of females with placental scars (16.3\%) and scars per uterus (except two cases with 13 and 16 respectively) and attributes it to the brief duration of the maculae cyane in the population from the Ebro Delta. The higher proportions and the close relationship observed between age and number of scars indicate a longer presence of scars in the population of southern Navarre. This fact has made it possible to estimate the approximate number of gestations. An adult female (age classes IV and V) has 1-6 litters per year, averaging 2-3, whereas Le Louarn and Saint Girons (1977) indicate 3-4. The existence of post-partum oestrus, observed in Arvicola sapidus, has been noted in other arvicolids (Horsfall and Butterstein 1979, Jannett et al. 1979, Morel 1981, Macfarlane and Taylor 1982, Guedon et al. 1991).

\section{Reproductive cycle}

The reproductive cycle of $A$. sapidus in southern Navarre is similar to the one observed by Delost (1968) and by Ventura and Gosálbez (1987) and follows, in general, the rodent reproduction scheme in mean latitudes (Saint-Girons 1973). Nevertheless, the period duration of high reproductive activity varies gradually from North to Southeast. This period would stretch in the Tarn river (Delost 1968), from April to September, in southern Navarre from March to October and in the Ebro Delta from February to October. These results show the influence of geographic or climatic factors on the reproductive activity of the water vole (cf also Pelikán 1972). The winter reproduction of arvicolids in central and northern Europe is cited as something exceptional (Smyth 1966, Spitz 1974, Meylan and Airoldi 1975, Moravec 1985). However, in the Mediterranean area, they often maintain sexual activity throughout the entire year (Claramunt 1976).

\section{References}

Báscones J. C. and Ursúa M. C. 1986. Estudio fitosociológico de los pastos de la Ribera Tudelana. Príncipe de Viana (Suplemento de Ciencias) 6: 101-140.

Bronson F. H. 1988. Seasonal regulation of reproduction in mammals. [In: The physiology of reproduction. E. Knobile and J. D. Neill, eds]. Raven Press, New York: 1831-1872.

Cabrera A. 1914. Fauna Ibérica: Mamíferos. I. N. C. Físico-Naturales, Madrid: 1-441.

Creus J. 1986. Climatología. [In: Gran Atlas de Navarra. Geografia. A. Floristán, eds]. Caja de ahorros de Navarra, Pamplona: 75-90.

Claramunt T. 1976. Sobre la actividad sexual de Pitymys duodecimcostatus de Selys-Longchamps, 1839, en Cataluña. Publicaciones Departamento de Zoología 1: 47-54. 
Delost P. 1968. Étude comparative de la reproduction chez quelques Rongeurs sauvages non hibernants dans differents régions de France. Entretiens de Chizé Physiologie 1: 23-50.

Durán A. C., Camprodón F. J., Cardo M. and Sans-Coma V. 1987. La reproducción de Mus spretus Lataste, 1883 en el N-NE de la Península Ibérica. [In: Mamíferos y helmintos. Volumen homenaje al Prof. Dr. Herman Kahmann en su 81 aniversario. V. Sans-Coma, eds]. Ed. Ketres, Barcelona: 111-120.

Garde J. M. 1992. Biología de la rata de agua Arvicola sapidus Miller, 1908 (Rodentia, Arvicolidae) en el Sur de Navarra (España). Ph D thesis, Universidad de Navarra, Pamplona: 1-496.

Garde J. M. and Escala M. C. 1993. Fluctuación anual del peso corporal de los machos adultos de Arvicola sapidus Miller, 1908 (Rodentia, Arvicolidae). Doñana Acta Vertebrata 20: 251-255.

Garde J. M., Escala M. C. and Ventura J. 1993. Determinación de la edad relativa en la rata de agua meridional, Arvicola sapidus Miller, 1908 (Rodentia, Arvicolidae). Doñana Acta Vertebrata 20: 266-276.

Gosálbez J. 1982. Contribución al conocimiento de los roedores del nordeste de la Península Ibérica y su interés biológico. Publicaciones de la Universidad de Barcelona, Barcelona: 1-55.

Gosálbez J., López-Fuster M. J. and Durfort M. 1979. Ein neues Färbungsverfahren für Hodenzellen von Kleinsäugetieren. Säugetierkundliche Mitteilungen 27: 303-305.

Guédon G., Pascal M. and Mazquin F. 1991. Le campagnol provenal en captivité (Pitymys duodecimcostatus de Sélys-Longchamps, 1839) (Rongeurs, Microtidés). I. La reproduction. Mammalia 55: 97-106.

Horsfall S. M. and Butterstein G. M. 1979. Reproduction in the pine vole, Microtus pinetorum. Journal of Mammalogy 60: 841-844.

Jannett F. J., Jannett J. A. and Richmond M. E. 1979. Notes on reproduction in captive Arvicola richardsoni. Journal of Mammalogy 60: 837-838.

Kenagy G. J. and Trombulak S. 1986. Size and function of mammalian testes in relation to body size. Journal of Mammalogy 67: 1-22.

Le Louarn H. and Saint-Girons M. C. 1977. Les Rongeurs de la France. Faunistique et biologie. INRA, Paris: $1-159$.

Macfarlane J. D. and Taylor J. M. 1982. Prenancy and reproductive performance in the Townsend's vole Microtus townsendii (Bachman). Journal of Mammalogy 63: 165-168.

Martinet L. and Spitz F. 1971. Variations saisonnires de la croissance et de la mortalité du Campagnol des champs, Microtus arvalis. Rôle du photopériodisme et de la végétation sur ces variations. Mammalia 35: 38-84.

Meylan A. and Airoldi J. P. 1975. Reproduction hivernale chez Arvicola terrestris scherman (Mammalia, Rodentia). Revue suisse de Zoologie 82: 689-694.

Moravec J. 1985. Age structures in a population of Microtus arvalis during its population cycle (Mammalia: Rodentia). Věstník Československé Společnosti Zoologické 49: 123-131.

Morel J. 1981. Le campagnol terrestre, Arvicola terrestris (L.), en Suisse: biologie et systématique (Mammalia, Rodentia). Ph D thesis, Université de Lausanne, Lausanne: 1-85.

Newson R. 1963. Differences in numbers, reproduction and survival between two neighboring populations of bank voles (Clethrionomys glareolus). Ecology 44: 110-120.

Pelikán J. 1972. Arvicola terrestris (L.) indexes of reproduction in Czechoslovakia. Acta scientiarum naturalium Academiae scientiarum Bohemicae Brno 11: 3-50.

Reichstein H. 1982. Gattung Arvicola Lacépde, 1799. [In: Handbuch der Säugetiere Europas. Bd. 2. J. Niethammer and F. Krapp, eds]. Akademische Verlagsgesellschaft, Wiesbaden: 209-252.

Rissman E. F. and Johnston R. E. 1986. Nutritional and social cues influence the onset of puberty in California voles. Physiology and Behavior 36: 343-347.

Rowlands I. W. and Weir B. J. 1984. Mammals: non-primate eutherians. [In: Marshall's physiology of reproduction. Vol. 1: Reproductive cycles of vertebrates. G. E. Lamming, ed]. Livingstone Editors, Edinburgh: 455-658.

Saint-Girons M. C. 1967. Etude du Genre Apodemus Kaup, 1829 en France. Mammalia 30: 547-600. 
Saint-Girons M. C. 1973. Les mammiferes de France et du Benelux. Faune marine exceptée. Doin Ed, Paris: $1-481$.

Smyth M. 1966. Winter breeding in woodland mice, Apodemus sylvaticus, and voles, Clethrionomys glareolus and Microtus agrestis, near of Oxford. Journal of Animal Ecology 35: 471-485.

Spitz F. 1974. Démographie du campagnol des champs Microtus arvalis en Vendée. Annales de Zoologie, Écologie animal 6(2): 259-312.

Ventura J. 1988. Contribución al conocimiento del género Arvicola Lacépde, 1799, en el nordeste de la Península Ibérica. Ph D thesis, Universidad de Barcelona, Barcelona: 1-590.

Ventura J. and Gosálbez J. 1987. Reproductive biology of Arvicola sapidus (Rodentia, Arvicolidae) in the Ebro delta (Spain). Zeitschrift für Säugetierkunde 52: 364-371.

Zabala J. 1983. Primera cita de Arvicola sapidus (Miller, 1908, Mammalia, Rodentia) para la provincia de Guipúzcoa. Munibe 35: 109-114.

Received 20 July 1995, revised 17 September 1996, accepted 18 September 1996. 